\title{
The millipede genus Argentocricus Verhoeff, 1941 (Diplopoda: Spirobolida: Rhinocricidae)
}

\section{Авупарноногие многоножкки рода Argentocricus Verhoeff, 1941 (Diplopoda: Spirobolida: Rhinocricidae)}

\author{
R.L. Hoffman ${ }^{1 \dagger} \&$ S.I. Golovatch ${ }^{2}$

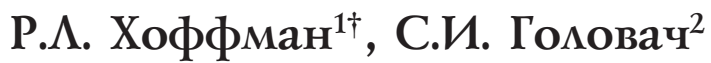

\footnotetext{
${ }^{1}$ Virginia Museum of Natural History, Douglas Ave. 1001, Martinsville, Virginia 24112, U.S.A; deceased on June $10^{\text {th }}$, 2012

${ }^{2}$ Institute for Problems of Ecology and Evolution, Russian Academy of Sciences, Leninsky pr. 33, Moscow 119071 Russia.

${ }^{2}$ Институт проблем экологии и эволюции РАН, Ленинский проспект, 33, Москва 119071 Россия.
}

KEY WORDS: Diplopoda, Rhinocricidae, Argentocricus, taxonomy, new species, South America.

КЛЮЧЕВЫЕ СЛОВА: Diplopoda, Rhinocricidae, Argentocricus, таксономия, новые виды, Южная Америка.

ABSTRACT. The full generic status of Argentocricus is reinstated, based on a mesal vesiculiform structure on the anterior gonopod telopodite, combined with a shorter, simpler, digitiform branch lying laterally of a longer and slender solenomere of the posterior gonopod. The following species are assigned to Argentocricus: A. nobilis Verhoeff, 1941 (the type species), A. bernardinensis (Carl, 1918), A. cataractarum (Schubart, 1962), A. gracilipes (Silvestri, 1897), A. indiscretus (Silvestri, 1897), A. nodulipes (Silvestri, 1897), all comb.n. ex Rhinocricus, as well as $A$. stylifer sp.n. and A. subtriangularis sp.n., both latter congeners from Argentina. All these species form a coherent geographical pattern restricted to southern South America.

РЕЗЮМЕ. Восстановлен полный родовой статус Argentocricus на основе наличия пузыреобразной структуры на телоподите передних гоноподов в сочетании с более короткой, простой, пальцеобразной ветви, лежащей в стороне от более длинного и тонкого соленомера задних гоноподий. Следующие виды относятся к Argentocricus: A. nobilis Verhoeff, 1941 (типовой вид), A. bernardinensis (Carl, 1918), A cataractarum (Schubart, 1962), A. gracilipes (Silvestri, 1897), A. indiscretus (Silvestri, 1897), A. nodulipes (Silvestri, 1897), все comb.n. ex Rhinocricus, а также $A$. stylifer sp.n. и $A$. subtriangularis sp.n., оба последних таксона из Аргентины. Все эти виды формируют четкий тип ареала, приуроченного к югу Южной Америки.

\section{Introduction}

The family Rhinocricidae is one of the largest not only in the order Spirobolida, but also in the entire class Diplopoda. At present, there are 543 nominal species and 23 subspecies of Rhinocricidae placed in
27 genera and three subgenera [Marek et al., 2003; González-Sponga, 2005; Rodrigues et al., 2012]. These juliform, often conspicuously large and colourful millipedes show two distinct and vastly disjunct centres of diversity, the largest in the Americas roughly between northern Mexico and the West Indies in the north and Uruguay + northern Argentina in the south, and the smaller in the Indo-Australian Archipelago together with parts of mainland Indochina and eastern Australia.

In general, the taxonomy of this family is very badly confused, especially so at the generic level [Hoffman, 1999]. Thus, as the rhinocricid fauna of South America appears to be dominated by species of a single genus whose name has not yet been adopted as settled, following Marek et al. [2003], we also tend to treat them provisionally in the all-embracing "Rhinocricus". In fact all of about 200 species or subspecies of "Rhinocricus", sometimes divided into species groups [Hoffman, 1999] or subgenera [Marek et al., 2003], are considered as occurring throughout the West Indies and South America, a few enigmatic forms even in Indo-Australia [Jeekel, 2001].

However, even against this huge, uniform and often inadequately described background, there are groups of species delimited not only by singular, distinctive morphological characters, but showing coherent geographical patterns. One such group appears to be represented by the southernmost genus Argentocricus Verhoeff, 1941. The present paper is an attempt to review it, based both on the available literature records and new material accumulated at the Virginia Museum of Natural History (VMNH).

\section{Taxonomic part}

Argentocricus was first proposed as a genus of full rank, with $A$. nobilis Verhoeff, 1941, from Estancia la 


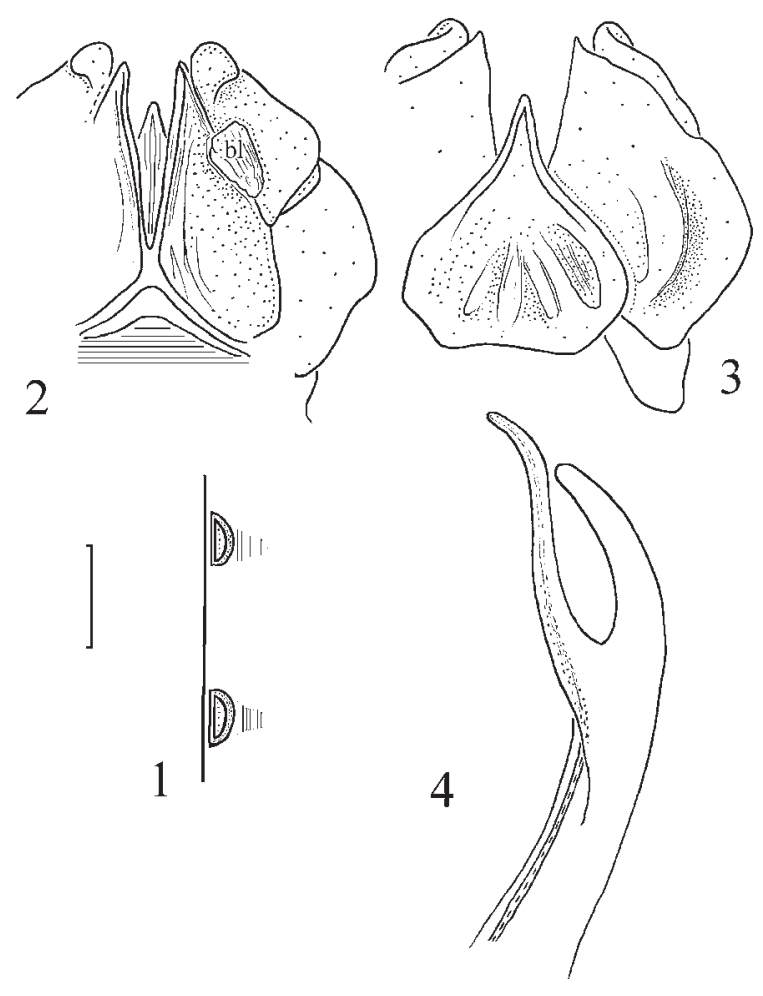

Figs 1-4. Argentocricus subtriangularis sp.n., holotype: $1-$ scobinae on segment $25 ; 2 \& 3$ - coleopods (= anterior gonopods), caudal and frontal views, respectively; 4 - tip of posterior gonopod. Scale bar: $1.0 \mathrm{~mm}(1-3)$, drawn not to scale (4).

Рис. 1-4. Argentocricus subtriangularis sp.n., голотип: 1 скобины на 25-м сегменте; 2, 3 - колеоподы (= передние гоноподы), соответственно сзади и спереди; 4 - вершина заднего гонопода. Масштаб: 1,0 мм (1-3), без масштаба (4).

Geraldina near Hersitia, Prov. Santa Fe, Argentina, serving as type species. The genus was diagnosed by the following combination of characters: (1) presence of vesiculiform structures on the caudal face of the anterior gonopod telopodites; (2) a very large coxal process on male leg-pair 3; (3) very fine longitudinal rugulosity of the metaterga, partly covering also the proterga so that the body is nearly silky in texture; and (4) very deep, pit-shaped scobinae [Verhoeff, 1941].

At first Schubart [1951] accepted this genus, though he failed to key it out against the remaining genera of Rhinocricidae known at that time. Later he [1962], based on the presence of conspicuous vesiculiform structures on the anterior gonopods, added to Argentocricus both his Rhinocricus cataractarum Schubart, 1962, from Paraguay, and R. nodulipes Silvestri, 1897, the latter species known from southern Bolivia, Mato Grosso, Brazil and northern Argentina, likely occurring also in Paraguay and Uruguay [Silvestri, 1897, 1902; Carl, 1918; Schubart, 1958, 1962]. Schubart [1962], considering the value of this character as dubious, treated Argentocricus as only a subgenus, a view recently adopted also by Marek et al. [2003]. Strangely enough, however, Schubart [1962] and Marek et al.
[2003] omitted Rhinocricus bernardinensis Carl, 1918, from Paraguay, and $R$. indiscretus Silvestri, 1897, from northern Argentina, both of which Carl [1918] regarded as being especially close to $R$. nodulipes. We are now able to add three additional species, $R$. gracilipes Silvestri, 1897, from Bolivia, and two new congeners. The opportunity is taken here to redefine Argentocricus, to resurrect its generic status, as well as to key all eight currently known species.

\section{Species descriptions}

\section{Argentocricus subtriangularis sp.n. Figs $1-4$.}

MATERIAL. Holotype O' (VMNH) labeled only "La Bolsa" [without further locality], 9-11 December 1961, leg. H. C. Hepper. Paratype $\sigma^{7}(\mathrm{VMNH})$, same data as holotype.

The only place by this name known to us (from the 1963 Esso road map of Argentina) is located in the Parque Nacional los Alerces, NE of Esquel, Prov. Chubut.

NAME. To emphasize the subtriangular median sternal process of the coleopods.

DESCRIPTION. Holotype with 55 (0) segments. Length ca $80 \mathrm{~mm}$, segments circular, diameter ca 7 $\mathrm{mm}$. Coloration castaneous brown, pattern cingulated, from dark brown mesozona and light brown to reddish brown metazona. A dark marking at location of ozopores evident along body as a dark horizontal line. Legs and antennae dark brown, only labrum, mouthparts and some anterior legs lighter.

Face typical, ocelli in 6 transverse rows, rounded, blackish, poorly distinguished, like black spots on dark background, from back forward 8-8-8-8-5-5 (= 42). Collum subtriangular and broadly rounded laterally, margined anteriorly and laterally but not caudally. Antennae of normal form, with numerous apical sensory cones. Ozopores beginning on segment 6, located immediately in front of or touching the meso-metazonal suture, which describes an evident semicircular emargination just above the pore; a similar emargination occurs just below the pore on segments 6-12 only. Metazona with fine striations ventrolaterally, reduced in size after segment 7 , continuing onto mesozona to disappear roughly at level of ozopores, prozona very finely transversely striolate. Scobinae present in reduced size on segments 5-7, decreasing in size posteriad of segment 50 , disappearing by segment 52 , at midbody relatively small (Fig. 1), separated by about $2.5 \mathrm{X}$ the width of one; area subreniform with a deep ellipsoidal groove posteriorly; scobinella poorly developed, only half as wide as arena, very finely striolate transversely.

Epiproct very short, not extended over paraprocts, its distal fourth offset to a lower level by a transverse depression. Hypoproct transversely semicircular, paraprocts with only a very shallow submarginal depression beside caudal edge, latter rounded.

Coxal process on leg 3 as in Fig. 6, decreasing in size from 3rd to 7 th posteriad. Podomeres without ventral pads. One or two small spines ventrally, one spine dorsally of claw. 
Coleopods (= anterior gonopods) (Figs 2 \& 3) with a distinct, triangular, narrowly rounded, median, sternal projection; inner coxal folds subacuminate apically; caudal face of telopodite with a conspicuous membranous sac, or vesicle $(b l)$, mesally in basal onethird extent. Posterior gonopod (Fig. 4) with a shorter, simpler, digitiform branch laterally of a longer, slightly sinuate, slender solenomere.

Paratype with $53(0)$ segments, length ca $80 \mathrm{~mm}$, width and height ca $7 \mathrm{~mm}$ at midbody. Coloration dark brown, cingulation not so evident, with narrower light brown rings represented on posterior half of metazona and on entire prozona. Epiproct paler and slightly projecting beyond curvature of paraprocts, broadly rounded in dorsal view; scobinella usually subtrangular rather than ribbon-shaped; in all other respects the specimen agreeing closely with holotype.

REMARK. This seems to be the southernmost representative not only of the genus, but also of the family, order and even all Chilognatha in the Western Hemisphere and World [Shelley \& Golovatch, 2011].

\section{Argentocricus stylifer sp.n.}

Figs 5-10.

MATERIAL. Holotype $\sigma^{7}$ (VMNH) from "La Soledad", Dept. Cruz Alta, Prov. Tucuman, Argentina, 16 December 1965, leg. Enrique H. Bucher. Paratypes: $1 \sigma^{r}, 1+(\mathrm{VMNH})$, same data as holotype.

NAME. To emphasize the styletiform median sternal process of the coleopods.

DESCRIPTION. Holotype with 50 (0) segments. Length ca $85 \mathrm{~mm}$ (specimen fragmented), diameter ca $9.0 \mathrm{~mm}$. Colour of preserved specimen dark greyish brown with a vivid cingulation pattern formed by broad reddish yellow prozona and most of all of metazona, caudal areas of epiproct, paraprocts, and hypoproct reddish. Labrum and all margins of collum broadly reddish yellow. Ozopores as in A. subtriangularis sp.n., each with a dark brown mark, forming collectively a dark lateral stripe. Striation of segments as in A. subtriangularis sp.n. Head of usual form, ocelli in a rounded cluster, in 6 rows, 8-8-8-8-6-4 (=42). Antennae with numerous sensory cones, antennomeres of usual form. Lateral ends of collum broadly subcircular, margined anterolaterally. Segmental texture coriaceous, somewhat shiny. Scobinae (Fig. 5) rudimentary on segment 5, thence larger to 8th, typically large and deep, subreniform, separated by distance slightly greater than one diameter, area with a deep crescentic posterior groove, scobinellae short, broad, very finely striated, size decreasing posteriad, only rudimentary on segment 49 . Epiproct slightly projecting beyond paraprocts, flattened in lateral aspect, subrectangular in dorsal aspect and broadly rounded, apical fourth slightly offset by a transverse groove; paraprocts evenly convex, without submarginal groove, margin rounded; hypoproct transversely subtriangular, edge broadly rounded, very slightly concave at base. Tarsi with one spine above and two below base of claw. Coxal processes of leg 3

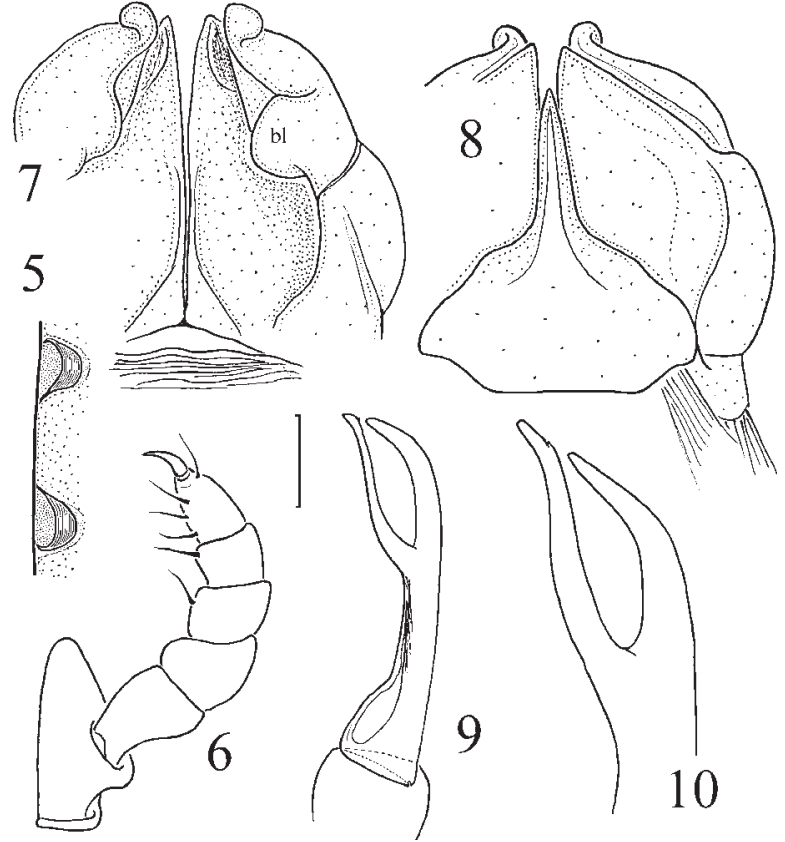

Figs 5-10. Argentocricus stylifer sp.n., holotype: 5 - scobinae on segment $25 ; 6-\operatorname{leg} 3 ; 7 \& 8-$ coleopods, caudal and frontal views, respectively; 9 - posterior gonopod; 10 - tip of posterior gonopod. Scale bar: $1.0 \mathrm{~mm}$ (5-9), drawn not to scale (10).

Рис. 5-10. Argentocricus stylifer sp.n., голотип: 5 - скобины на 25-м сегменте; 6 - 3-я нога; 7, 8 - колеоподы, соответственно сзади и спереди; 9 - задний гонопод; $10-$ вершина заднего гонопода. Масштаб: 1,0 мм (5-9), без масштаба (10).

(Fig. 6) with a subtriangular process/lobe, lobes of coxae 4 and 5 similar but strongly reduced in size.

Gonopods (Figs $7 \& 8$ ): Median projection of coleopod sternum long and slender, styletiform, with a low median ridge; coxal plates extending only a slight distance beyond apex of sternum, with a prominent groove near lateral margin. Telopodite about as long as coxae, its apex reflexed, inner surface of telopodite at base with a moderate-sized, projecting, membranous vesicle (Figs $7 \& 8, b l$ ). Posterior gonopods (Figs $9 \&$ 10) typical for the genus, apex of solenomere with a minute marginal denticle.

Paratype $\sigma^{7}$ with $52(0)$ segments. Length ca 55 $\mathrm{mm}$, diameter ca $6.0 \mathrm{~mm}$. Coloration similar to holotype, except coloration yellowish without reddish tones. Structural features as described for holotype, except 6 rows of ocelli, 7-8-8-7-4-3.

Paratype + similar in coloration to holotype, cingulation reddish. Body with 55 segments. Length 63 $\mathrm{mm}$, diameter $7 \mathrm{~mm}$. Ocelli in 6 rows: $8-9-7-7-6-4$ $(=41)$. Structural details otherwise as described for holotype.

\section{Concluding remarks}

Schubart [1962] was certainly right to doubt most if not all of the characters of Argentocricus as formulated 


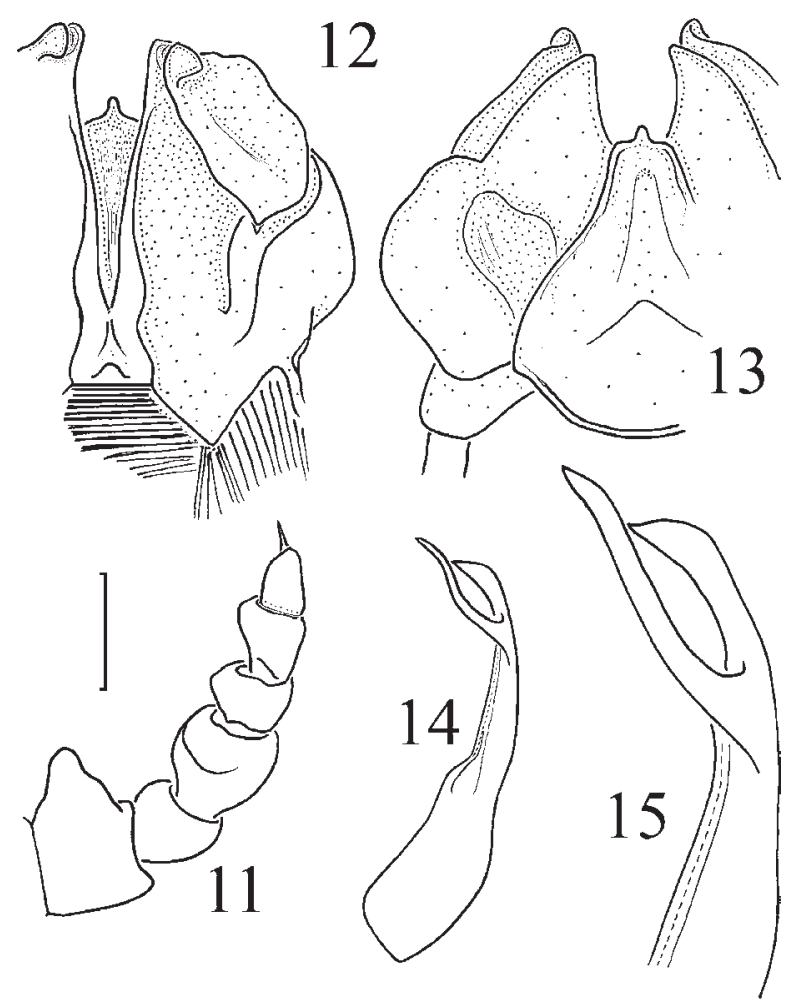

Figs 11-15. "Rhinocricus" sp., o from 7 km north of Posadas, Prov. Misiones, Argentina, 12 January 1977, leg. L.A. Pereira (VMNH): 11 - leg 3; 12 \& 13 - coleopods, caudal and frontal views, respectively; 14 - posterior gonopod; 15 - tip of posterior gonopod. Scale bar: $1.0 \mathrm{~mm}$ (11-14), drawn not to scale (15).

Рис. 11-15. "Rhinocricus" sp., О7 из Аргентины (7 km north of Posadas, Prov. Misiones, Argentina, 12 January 1977, leg. L.A Pereira (VMNH)): 11 - 3-я нога; 12, 13 - колеоподы, соответственно сзади и спереди; 14 - задний гонопод; 15 - вершина заднего гонопода. Масштаб: 1,0 мм (11-14), без масштаба (15).

by Verhoeff [1941] (see above). However, even he admitted that the few species in southern South America that looked closer to one another than to any other "Rhinocricus" could be pulled together and kept separately as a subgenus Argentocricus. We can add here that such a character as relative length of the coxal process on male leg 3 does not seem to hold. Thus, both in A. subtriangularis sp.n. (Fig. 6) and A. stylifer sp.n., the coxal process is considerably shorter than that in A. nobilis [see Verhoeff, 1941], yet somewhat longer, virtually usual, than in some "Rhinocricus" species, even parapatric ones (Fig. 11). As a silky tergal texture seems characteristic of numerous "Rhinocricus" species, this trait, too, can hardly be considered as useful in diagnosing Argentocricus. So what does remain diagnostic is a mesal vesiculiform structure on the coleopod telopodite, combined with a shorter and simpler branch lying laterally of a longer and slender solenomere of the posterior gonopod. However, even this can prove to be tricky, as one can see from Figs 11-15, showing a "Rhinocricus" from northern Argentina, in which the posterior gonopod is nearly as simple as in Argentocricus. Still the outer branch of the poste- rior gonopod in this form is flattened and subtriangular at tip (Fig. 15), while a vesicle on the coleopod telopodite is wanting.

A refined diagnosis of Argentocricus would thus read as follows: (1) a more or less conspicuous vesiculiform membranous structure present mesally on the coleopod telopodite; (2) posterior gonopod with a shorter, simpler, digitiform branch laterally of a longer and slender solenomere. As another potentially useful character might prove to be the lack of a premarginal sulcus on the paraprocts.

At present, the following species can be attributed to Argentocricus: A. nobilis Verhoeff, 1941 (the type species), A. bernardinensis (Carl, 1918), A. cataractarum (Schubart, 1962), A. gracilipes (Silvestri, 1897), A. indiscretus (Silvestri, 1897), A. nodulipes (Silvestri, 1897), all comb.n. ex Rhinocricus, as well as $A$. stylifer sp.n. and $A$. subtriangularis sp.n. All these species form a coherent geographical pattern restricted to southern South America.

Since some of the earlier descriptions are regrettably too short and imperfect, the key below must only be understood as provisional.

\section{Key to ARGENTOCRICUS SPECIES}

1. Posterior gonopod solenomere about 2 times as long as adjacent digitiform branch; male coxa 3 with a relatively short apophysis; Bolivia ......................... A. gracilipes

- Posterior gonopod solenomere only modestly longer than adjacent digitiform branch (Figs 2, 3, 9 \& 10); male coxa 3 with a relatively long apophysis (Fig. 6) .......... 2

2. Apical half of coleopod sternum like a long, narrow, stylet-shaped process (Fig. 8); bl modest in size (Fig. 7); N. Argentina ........................................ A. stylifer sp.n.

- Apical half of coleopod sternum more or less triangular, even if process-shaped, then shorter and not styletiform; $b l$ of coleopod usually more conspicuous ................... 3

3. Coloration brown, edges of collum broadly yellow-brown, caudal edges of metazona narrowly yellow-brown; scobinae beginning on segment 8; Paraguay

\section{A. bernardinensis}

- Coloration usually darker, blackish to greyish, edges of collum and cingulation thereafter normally reddishbrown; even if edges yellow-brown or red-yellow, then background coloration black or dark grey; scobinae starting either before or after segment 8

4. Coloration black, edges of collum and cingulation thereafter yellowish to brownish; scobinae beginning on segment 9; both male coxae 3 and 4 with high, rounded apophyses; N. Argentina A. indiscretus

- Edges of collum and cingulation thereafter reddish-brown to red-yellow; scobinae beginning on segment 7 or even before; castaneous brown; apophysis on male coxae 4 usually much shorter than that on coxae 3 ................ 5

5. Distal part of coleopod sternum like an equilateral triangle; apophysis on male coxae 4 only slightly shorter and more rounded than that on coxae 3; W. Paraná, Brazil A. cataractarum

- Distal part of coleopod sternum like a process; apophysis on male coxae 4 much shorter than that on coxae $3 \ldots 6$

6. Coloration lead grey; process on male coxa 3 long, digitiform, broadly rounded at tip ................ A. nobilis 
- Coloration in alcohol castaneous brown to brownish black; process on male coxa 3 subtriangular, subacuminate or rounded at tip

7. Scobinae beginning on segment 6 ; process in apical third of coleopod sternum more broadly rounded at tip; process on male coxa 3 subacuminate; Bolivia and Mato Grosso, Brazil A. nodulipes

- Scobinae somewhat reduced on segments 5-7, onward fully developed; process in apical $1 / 3$ of coleopod sternum subacuminate (Fig. 3); process on male coxa 3 rounded at tip; N. Argentina ... A. subtriangularis sp.n.

ACKNOWLEDGEMENTS. We are most grateful to the collectors, whose material has been used in the present work.

\section{References}

Carl J. 1918. Miscellanées diplopodologiques // Rev. suisse Zool. T.26. Fasc.13. P.417-468

González-Sponga M.Á. 2005. Miriápodos de Venezuela. Diez nuevas especies del género Rhinocricus (Spirobolida: Rhinocricidae) // Revista de Investigación. No.57. P.13-48.

Hoffman R.L. 1999. Checklist of the millipeds of North and Middle America // Virginia Mus. Nat. Hist. Spec. Publ. No.8. P.1584.

Jeekel C.A.W. 2001. A bibliographic catalogue of the Spirobolida of the Oriental and Australian regions (Diplopoda) // Myriapod Memoranda. Vol.4. P.5-104.
Marek P.E., Bond J.E., Sierwald P. 2003. Rhinocricidae systematics II: A species catalog of the Rhinocricidae (Diplopoda: Spirobolida) with synonymies // Zootaxa. No.308. P.1-108.

Rodrigues P.E.S., Ott R., Rodrigues E.N.L. 2012. New species and new records of millipedes of the genus Rhinocricus Karsch, 1881 (Spirobolida: Rhinocricidae) from southern Brazil // Ibid. No.3172. P.55-64.

Schubart O. 1951. Contribuição para a fauna do Estado de São Paulo II. Os Rhinocricidae (Opisthospermophora, Diplopoda) // Anais Acad. brasil. Ciênc. Vol.23. No.2. P.221-275.

Schubart O. 1958. Sôbre algunos Diplopoda de Mato Grosso e Goiás, Brasil e a familia Spirostreptidae // Arch. Mus. Nac. Rio de Janeiro. Vol.46. P.203-252.

Schubart O. 1962. Novas espécies brasileiras de família Rhinocricidae (Diplopoda, Opisthospermophora) // Anais Acad. brasil. Ciênc. Vol.34. No.1. P.69-87.

Shelley R.M., Golovatch S.I. 2011. Atlas of myriapod biogeography. I. Indigenous ordinal and supra-ordinal distributions in the Diplopoda: Perspectives on taxon origins and ages, and a hypothesis on the origin and early evolution of the class // Insecta Mundi. No.0158. P.1-134

Silvestri F. 1897. Viaggio del Dott. Alfredo Borelli nel Chaco boliviano e nella Repubblica Argentina. IV. Chilopodi e diplopodi // Boll. Mus. Zool. Anat. comp. Univ. Torino. Vol.12. No.283. P.1-11.

Silvestri F. 1902. Viaggio del Dr. A. Borelli nel Matto Grosso. VII // Ibid. Vol.17. No.432. P.1-25.

Verhoeff K.W. 1941. Über Spirostreptiden Südamerikas, vergleichenden Morphologie und Mechanik der Gonopoden und eine neue Rhinocriciden-Gattung // Arch. Naturg., N.F. Bd.10. H.2. S.278-302.

Responsible editor K.G. Mikhailov 